\title{
Variations of $\mathrm{O}_{3}$ and $\mathrm{CO}$ in summertime at a rural site near Beijing
}

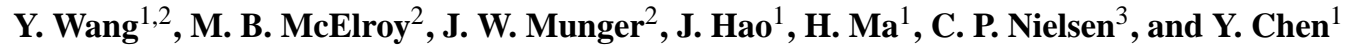 \\ ${ }^{1}$ Department of Environmental Science and Engineering, Tsinghua University, Beijing, China \\ ${ }^{2}$ Department of Earth and Planetary Sciences and School of Engineering and Applied Sciences, Harvard Univ., Cambridge, \\ Massachusetts, USA \\ ${ }^{3}$ Harvard China Project and School of Engineering and Applied Sciences, Harvard Univ., Cambridge, Massachusetts, USA
}

Received: 11 April 2008 - Published in Atmos. Chem. Phys. Discuss.: 3 June 2008

Revised: 1 September 2008 - Accepted: 19 September 2008 - Published: 5 November 2008

\begin{abstract}
Large intra-season differences in mixing ratios of $\mathrm{CO}$ and $\mathrm{O}_{3}$ were detected at Miyun, a rural site north of Beijing, in summer 2006. Despite an increase in mean daytime mixing ratio of CO from $500 \mathrm{ppbv}$ in June to $700 \mathrm{ppbv}$ in July, mean daytime $\mathrm{O}_{3}$ dropped from $67 \mathrm{ppbv}$ in June to 50 ppbv in July and August. The observed changes in $\mathrm{CO}$ and $\mathrm{O}_{3}$ are attributed to the influence of the summer monsoonal circulation that develops over the North China Plain in July. Photochemical production of $\mathrm{O}_{3}$ is reduced as a consequence of increased cloudiness during July and August, as indicated by the strong negative correlation observed between $\mathrm{O}_{3}$ and satellite observations of cloud optical depth, with cloudiness having little effect on $\mathrm{CO}$. The analysis suggests a strategy for emission controls that could be implemented in an economically efficient manner to minimize the frequency of high levels of $\mathrm{O}_{3}$ during summer in Beijing.
\end{abstract}

\section{Introduction}

China's rapid economic growth in recent years has been fueled largely by fossil energy especially coal (NBS, 2007), resulting in large increases in pollutant emissions (Zhang et al., 2007) with implications for tropospheric chemistry on both regional and global scales. It is an urgent need for the scientific community to understand the chemical and dynamical transformations of Chinese emissions as well as to evaluate three-dimensional chemical transport models employed to simulate their implications. Previous studies analyzing the few short-term measurements of trace gases within and downwind of China (Wang et al., 2002, 2004b; Jacob et al., 2003) have provided valuable constraints on Chinese emissions of carbon monoxide $(\mathrm{CO})$ and nitrogen oxides $\left(\mathrm{NO}_{\mathrm{x}}\right)$

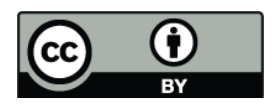

Correspondence to: Y. Wang

(yxw@mail.tsinghua.edu.cn)
(Wang et al., 2004a; Tan et al., 2004; Heald et al., 2004). In comparison to North America and Europe, however, nearsource and long-term atmospheric measurements of important trace gases such as ozone $\left(\mathrm{O}_{3}\right)$ have been sparse, if not absent, in China.

Ozone is produced in the troposphere by photochemical oxidation of volatile organic carbons (VOCs) and CO in the presence of $\mathrm{NO}_{\mathrm{x}}$. It is also transported from the stratosphere to the troposphere. High concentrations of $\mathrm{O}_{3}$ near the surface have an adverse impact on human health and vegetation (NRC, 1991). In view of the importance of $\mathrm{O}_{3}$ to air quality and atmospheric chemistry, several groups have put forth great effort to obtain in-situ measurements of $\mathrm{O}_{3}$ in China (Wang et al., 2002, 2005; Lin et al., 2008; Ding et al., 2008; Gao et al., 2005), as summarized below. But the current understanding of the temporal and spatial distribution of tropospheric ozone in China is far from complete.

Previous year-long observations at a rural site (Lin An) near the Yangtze River Delta region in central east China (Wang et al., 2002) and a coastal site (Tai O) near Hong Kong in south China (Wang et al., 2005) showed that $\mathrm{O}_{3}$ did not show high levels in summer, in contrast to the pattern observed typically in North America and Europe (maxima in summer). Instead, surface ozone was found to peak in spring at Lin An (Wang et al., 2002) and in autumn at Tai O (Wang et al., 2005). Earlier observations of surface ozone at two non-urban sites in north China indicated peaks in autumn and early winter with relatively low concentrations in summer (Luo et al., 2000). Seasonal cycles of surface ozone measured at a rural site (Shangdianzi) near Beijing (Lin et al., 2008) and derived from multi-year records of the MOZAIC aircraft data over Beijing (Ding et al., 2008) showed a narrow seasonal maximum of ozone in June followed by a substantial decrease in July and August. These studies suggested that the monsoonal circulation in East Asia had significant influences on seasonal variability of ozone in China, but the mechanism controlling ozone levels in summer was not well

Published by Copernicus Publications on behalf of the European Geosciences Union. 
(a)

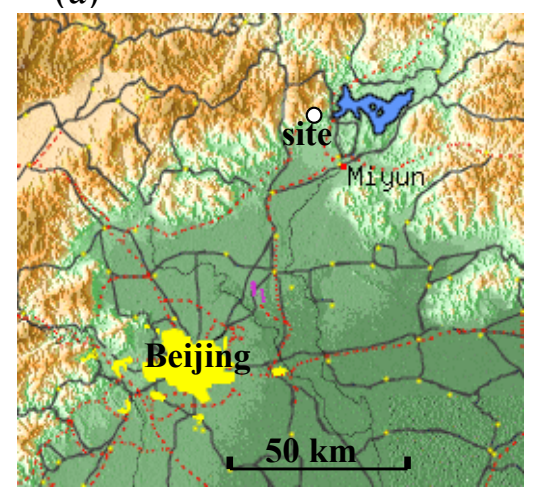

(b) Miyun site and Chinese $\mathrm{CO}$ emissions in 2001

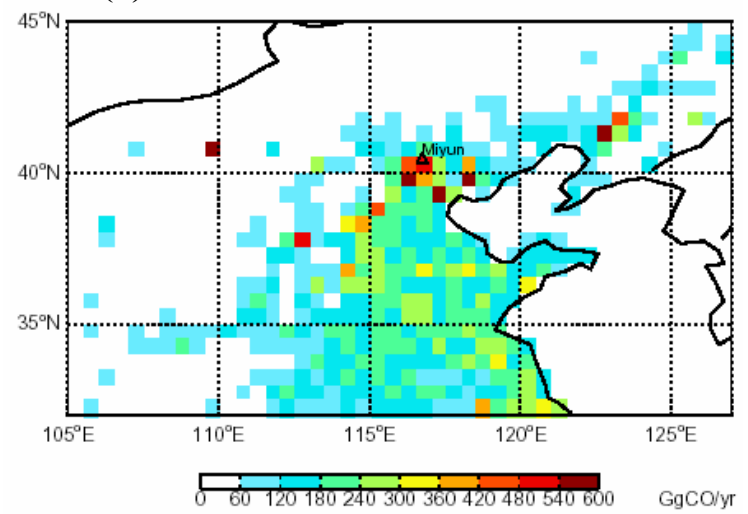

Fig. 1. (a) A regional map shows the location of the site (white circle) relative to Beijing urban area and other population centers(yellow), major roads (red), airport (magenta), and terrain. The color shading indicates elevation from low (green - near sea level) to high (darkest brown corresponding to $1400 \mathrm{~m}$ ). Miyun city is indicated by the red dot. (b) Annual emissions of CO from fossil and bio-fuel combustion $\left(0.5^{\circ} \times 0.5^{\circ}\right)$ in North China (Streets et al., 2006). The Miyun site is indicated.

understood. The summer monsoon with its typical maritime inflow could impact ozone levels in many different ways, such as diluting ozone and its precursors by convection, removing precursors by wet scavenging, or reducing photochemical production of ozone by increasing cloudiness. At the few rural sites in China, monthly mean daytime mixing ratios of $\mathrm{O}_{3}$ for the peak month range from 50 to $60 \mathrm{ppbv}$. In contrast to these rural observations, very high mixing ratios of $\mathrm{O}_{3}$ (1-h $\mathrm{O}_{3}$ up to $286 \mathrm{ppbv}$ ) were reported in urban plumes of Beijing in June (Wang et al., 2006). Analysis of the Beijing plume showed that $\mathrm{O}_{3}$ was strongly correlated with total reactive nitrogen $\left(\mathrm{NO}_{\mathrm{y}}\right)$ and this positive relationship extended to very high concentrations of $\mathrm{NO}_{\mathrm{y}}$, suggesting the important role of $\mathrm{NO}_{\mathrm{x}}$ in the formation of $\mathrm{O}_{3}$.

Scarcity of high quality, near-source, long-term observations of $\mathrm{O}_{3}$ and relevant chemical species in China prompted a decision by the Harvard China Project and Tsinghua University to collaboratively deploy an atmospheric observation station at Miyun, a rural site $100 \mathrm{~km}$ northeast of Beijing. The location was selected to capture the dichotomy between relatively clean continental air and the Beijing urban plume. The purpose of this study is to demonstrate the effect of the summer monsoon on ozone production within the aged Beijing pollution plume and to use data from the Miyun site to evaluate atmospheric models. Variations of $\mathrm{O}_{3}$ and $\mathrm{CO}$ at Miyun in summer (June, July, and August; JJA) 2006 will be examined and interpreted using a three-dimensional global chemical transport model (CTM) validated against a variety of measurements from other regions of China (Wang et al., 2007a, b). $\mathrm{O}_{3}$ data and CTM simulations will be used to develop an understanding of the meteorological factors influencing summertime variations of $\mathrm{O}_{3}$ over Beijing. Limiting $\mathrm{O}_{3}$ to acceptable levels poses a difficult challenge for air quality regulators. Better understanding of the relevant physics and chemistry of $\mathrm{O}_{3}$ formation can play an important role in the introduction of cost effective measures to mitigate what has proved to be a difficult problem not only for China but also for other regions of the developed and developing world.

\section{Site description}

The Miyun site $\left(40^{\circ} 29^{\prime} \mathrm{N}, 116^{\circ} 46.45^{\prime} \mathrm{E}\right)$ is located at an elevation of about $152 \mathrm{~m}$ in Miyun County (population of about 420000 ), about $100 \mathrm{~km}$ northeast of the Beijing urban area (Fig. 1a). Mountains rise steeply to the north of the site, while the terrain to the south falls off gradually to about $90 \mathrm{~m}$ in a region characterized by a mix of agriculture and small villages. The prevailing monsoonal winds switch direction annually from cold, dry, northwesterly in winter to warm, moist, southwesterly in summer.

The station was established through a collaboration between the Harvard China Project and Tsinghua University. The latter assumed operational responsibility for the station in 2007. The measurements began in November 2004 and includes a suite of gases $\left(\mathrm{CO}, \mathrm{CO}_{2}, \mathrm{O}_{3}\right)$ complemented by basic meteorological data (temperature, relative humidity, wind speed and direction). The present study focuses on measurements of $\mathrm{CO}$ and $\mathrm{O}_{3}$ for the summer of 2006 .

The instruments are configured to allow precise, high accuracy measurements of the selected gases and are calibrated ultimately to NOAA/GMD primary standards allowing the new results to be merged with global trace-gas data sets. Ozone mixing ratios are measured by UV absorption (Thermo Environmental Instruments Model 49c). Sample air is drawn from an inlet above the roof on an instrument shed $5 \mathrm{~m}$ above ground level. CO mixing ratios are measured by infrared absorption (Thermo Environmental Instruments 
48CTL). Sample air is drawn from the same inlet as the $\mathrm{O}_{3}$ sample and pressurized to $10 \mathrm{psi}$ with excess air vented through a backpressure regulator. The sample is dried by a cold trap held at $2^{\circ} \mathrm{C}$ and Nafion drier in series. A flow controller upstream of the analyzer and a pressure controller downstream maintain constant pressure in the cell and regulate flow. Exhaust air from the analyzer is used to purge the Nafion dryer before venting to the room. Instrument zero is determined by diverting sample air through an oxidizing catalyst to remove CO (Foulger and Simmonds, 1993) for $3 \mathrm{~min}$ every $15 \mathrm{~min}$. Twice daily the instrument gain is determined by supplying NIST traceable standards (Scott-Marrin). In 2005 two standards were used at nominal mixing ratios of roughly 100 and 500 ppbv. In 2006 a third standard at 2500 ppbv was added to the system. Mixing ratios are determined by subtracting the zero value from measured voltage and computing concentration from a quadratic fit to the calibration data. Details of the instruments are described in more detail elsewhere (Munger et al., 2008).

\section{Model description}

The GEOS-Chem global 3-D model for tropospheric chemistry is employed in the present study to simulate surface concentrations of $\mathrm{O}_{3}$ and $\mathrm{CO}$ at the Miyun site. The model is driven by meteorological data assimilated by the Goddard Earth Observing System (GEOS-4) at the NASA Global Modeling and Assimilation Office (GMAO). The meteorological data include 3-D fields updated every $3 \mathrm{~h}$ for surface fluxes and mixing depths, and every $6 \mathrm{~h}$ for other variables. We use version 7-04-09 of GEOS-Chem (www-as.harvard. edu/chemistry/trop/geos) with a horizontal resolution of $2^{\circ}$ latitude by $2.5^{\circ}$ longitude and 30 vertical hybrid eta levels, extending from the surface to $0.01 \mathrm{hPa}$. The lowest $2 \mathrm{~km}$ is resolved using five layers with midpoints at 60, 250, 620, 1200 , and $1990 \mathrm{~m}$ altitude for a column based at sea level.

The GEOS-Chem model includes a detailed tropospheric $\mathrm{O}_{3}-\mathrm{NO}_{\mathrm{x}}$-hydrocarbon-aerosl simulation. The aerosol and oxidant chemistry are coupled through the formation of sulfate and nitrate, heterogeneous chemistry, and aerosol effects on photolysis rates. Photolysis frequencies are computed using the Fast-J radiative transfer algorithm (Wild et al., 2000) which allows for Rayleigh scattering as well as for Mie scattering by clouds and aerosols. Simulation of wet and dry deposition follows the schemes developed by Bey et al. (2001). Application and evaluation of the model over China has been described by Wang et al. (2004a, c). The model was spunup for a 12-month period beginning 1 January 2005 and run through 2006. Hourly model output sampled at the grid box that includes Miyun is used for comparison with observations.

Combustion sources of $\mathrm{NO}_{\mathrm{x}}$ over China were taken from a recent bottom-up inventory developed by Zhang et al. (2007) for 2004. The annual total is $17.8 \mathrm{TgNO}_{2}$ in 2004. This inventory was based on the work of Streets et al. (2001) and included many improvements on both emission factors and energy statistics. The model includes seasonally resolved microbial sources of $\mathrm{NO}_{\mathrm{x}}$ for China $\left(3.3 \mathrm{TgNO}_{2} / \mathrm{yr}\right)$, which were derived based on multi-year satellite observations of tropospheric $\mathrm{NO}_{2}$ columns up to 2000 (Wang et al., 2007a). Combustion sources of CO over China were adopted from the inventory of Streets et al. (2006). This inventory represents annual emissions of CO for 2001 (146 TgCO/yr; Fig. 1b). Anthropogenic emissions of other species (e.g. NMVOCs) over China were taken from the work of Streets et al. (2001). The biomass burning inventory is based on satellite observations of fires by van der Werf et al. (2006), and emission factors from Andreae and Merlet (2001).

\section{Variability of $\mathrm{O}_{3}$ and $\mathrm{CO}$ in summer}

Figure 2 presents monthly means and selected cumulative probability percentiles for daytime (9 a.m. -6 p.m.) mean mixing ratios of $\mathrm{CO}(2 \mathrm{a})$ and $\mathrm{O}_{3}(2 \mathrm{~b})$ observed at Miyun in JJA 2006. CO is included as a tracer indicating the frequency and magnitude of the influence from urban pollution plumes which contain $\mathrm{O}_{3}$ precursors, notably $\mathrm{NO}_{\mathrm{x}}$ and hydrocarbons. At Miyun the mean daytime mixing ratios of $\mathrm{CO}$ are $600 \mathrm{ppbv}\left(\mathrm{ppbv}=\mathrm{nmol} \mathrm{mole}^{-1}\right)$ in summer 2006, higher than the mean summertime CO levels observed at Lin An in the Yangtze River Delta (Wang et al., 2002) and at a coastal site (Tai O) near Hong Kong in south China (Wang et al., 2005) by $220 \mathrm{ppbv}$ and $400 \mathrm{ppbv}$, respectively. As will be shown below, the higher $\mathrm{CO}$ levels at Miyun reflect the influence of $\mathrm{CO}$ sources from the Beijing urban area located upwind of the site under the prevailing southwesterly winds in summer. By comparison, mean summertime $\mathrm{CO}$ mixing ratios at rural low-elevation sites in eastern North America are generally less than 200 ppbv (Chin et al., 1994; Liang et al., 1998; Mao et al., 2004).

While median CO levels increased by about 300 ppbv from June to July, monthly mean $\mathrm{O}_{3}$ decreased by 17 ppbv, from $67 \mathrm{ppbv}$ in June to around $50 \mathrm{ppbv}$ in July. The reduction in $\mathrm{O}_{3}$ is observed both in peak values and minima. Mixing ratios of $\mathrm{O}_{3}$ and $\mathrm{CO}$ observed in August are similar to values detected in July. In contrast to the maximum in $\mathrm{O}_{3}$ observed in springtime at Lin An in central-east China (Wang et al., 2002), $\mathrm{O}_{3}$ exhibits a clear peak in June at Miyun (daytime mean $\mathrm{O}_{3}$ is 55 ppbv in May, not shown). The $\mathrm{O}_{3}$ levels were found to peak also in June at another rural site north of Beijing (Shangdianzi) (Lin et al., 2008) and at a mountain site in the North China Plain (Mt. Tai) (Li et al., 2007). The surface ozone climatology over Beijing derived from the MOZAIC aircraft data (Ding et al., 2008) exhibits a narrow seasonal maximum in June.

The number of hours in each month with 1-h average $\mathrm{O}_{3}$ exceeding $200 \mu \mathrm{g} / \mathrm{m}^{3}$ (Chinese air quality standard at $1 \mathrm{~atm}$ and $25^{\circ} \mathrm{C}$, corresponding to $102 \mathrm{ppbv}$ ) decreases from $36 \mathrm{~h}$ 
(a) Daytime mean CO at Miyun in 2006

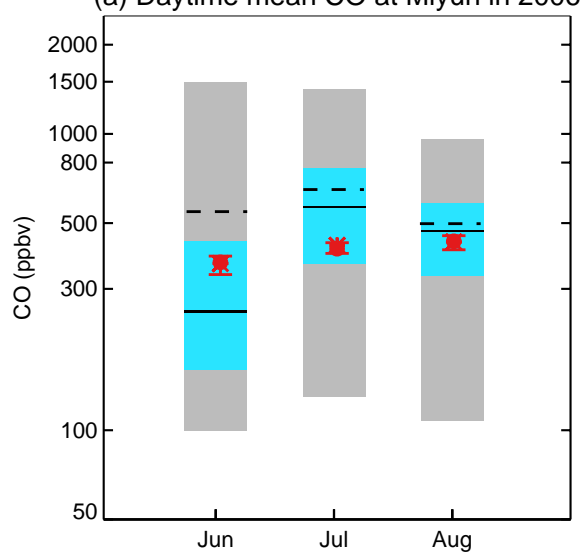

(b) Daytime mean $\mathrm{O}_{3}$ at Miyun in 2006

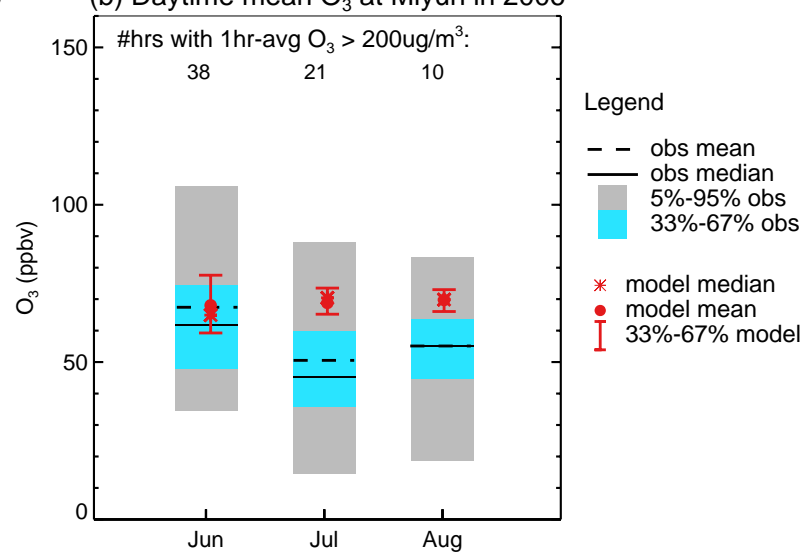

Fig. 2. (a) Daytime (9 a.m.-6 p.m.) mean mixing ratios of CO at the Miyun site in summer (JJA) 2006. Measurements are shown as bars and model simulations are in red. (b) Same as a, but for $\mathrm{O}_{3}$. The number of hours in each month with measured 1-h mean $\mathrm{O}_{3}$ exceeding $200 \mu \mathrm{g} / \mathrm{m}^{3}$ is indicated.

in June, to 21 in July, to 10 in August at Miyun. Wang et al. (2006) reported higher $\mathrm{O}_{3}$ in the summer of 2005 at a site slightly closer to the Beijing urban center. The correlation between $\mathrm{O}_{3}$ and $\mathrm{CO}$ used in previous studies to examine the influences of anthropogenic precursors on $\mathrm{O}_{3}$ (Chin et al., 1994; Parrish et al., 1998) is moderately positive in June $(r=0.6)$, insignificant in July $(r=0.1)$, and weak in August $(r=0.4)$. Although the figures present only summertime data for 2006, measurements in 2005 and 2007 exhibit similar decreases of $\mathrm{O}_{3}$ from June to July and August.

Model results sampled at the time of measurements (red) are compared with observations of $\mathrm{CO}$ and $\mathrm{O}_{3}$ in Fig. 2. Although the model is limited in resolution $\left(2^{\circ} \times 2.5^{\circ}\right)$ and restricted by the accuracy of emission inventories, it succeeds in capturing the increase in CO from June to July (Fig. 2a) (although the magnitude is underestimated, as is often the case with comparisons of point measurements with gridaveraged model predictions). The model fails, however, to account for the decrease in $\mathrm{O}_{3}$ from June to July and August. It tends to overestimate concentrations for the latter months (Fig. 2b).

4.1 Changes in meteorological conditions from June to July

Tropical Rainfall Measuring Mission (TRMM) data (http://disc.sci.gsfc.nasa.gov/data/datapool/TRMM/;

$0.5^{\circ} \times 0.5^{\circ}$ gridded monthly product comprised of mean hydrometeor profiles from the TRMM Microwave Imager (TMI) instrument on board the TRMM satellite) indicate that $85 \%$ of annual precipitation for the Beijing region during 2006 occurred in July and August. Monthly rainfall for July and August 2006 was $130 \mathrm{~mm}$ and $110 \mathrm{~mm}$ respectively, as compared to $10 \mathrm{~mm}$ for June, associated with the onset of East Asian summer monsoon rainfall.
Wind direction measured at the site exhibits distinctly different behavior between June and July. Although the prevailing winds were generally southwesterly during both months, northwesterly flow was observed frequently in June but not in July. The decrease in the frequency of northerly flow in July is associated with the full development of the summer monsoonal circulation which at this time brings moist, southerly, air to the region. In June, $40 \%$ of observations sampled at the site had less than $200 \mathrm{ppbv}$ of $\mathrm{CO}$, characteristic of cleaner continental air masses from the north. This cleaner air was encountered only $15 \%$ of the time in July, while the majority of the data indicated mixing ratios of $\mathrm{CO}$ exceeding $500 \mathrm{ppbv}$ reflecting the influence of polluted air masses from the Beijing urban area to the south (c.f. spatial distribution of $\mathrm{CO}$ sources in Fig. 1b). The increase in CO observed at Miyun from June to July can be attributed to more frequent transport of urban pollution to the site, consistent with the change in mean wind direction. The observed changes in mean flow pattern are reproduced by the GEOS-4 assimilated meteorology employed by the model.

Despite the increasing influence of urban pollution as indicated by $\mathrm{CO}, \mathrm{O}_{3}$ decreases in July. Increasing mixing ratios of $\mathrm{CO}$ indicate that dilution of $\mathrm{O}_{3}$ and its precursors by convective vertical mixing associated with the monsoonal rainfall in July has at most a minor influence. Observed daytime relative humidity (RH) at Miyun was 50\% higher in July than in June. For southerly flow, daytime RH was about $50 \%$ on average in June, compared with about $80 \%$ in July. As expected from the increases in $\mathrm{RH}$ and precipitation, cloud optical depth (COD) retrieved from the Moderate Resolution Imaging Spectroradiometer (MODIS) instrument aboard the Aqua satellite (Platnick et al., 2003; MYD08_M3, level-3 monthly global product at $1^{\circ} \times 1^{\circ}$ resolution) over the Beijing-Miyun region showed an increase of $83 \%$ from an average of 13 in June to 22 in July. Changes in COD, as 

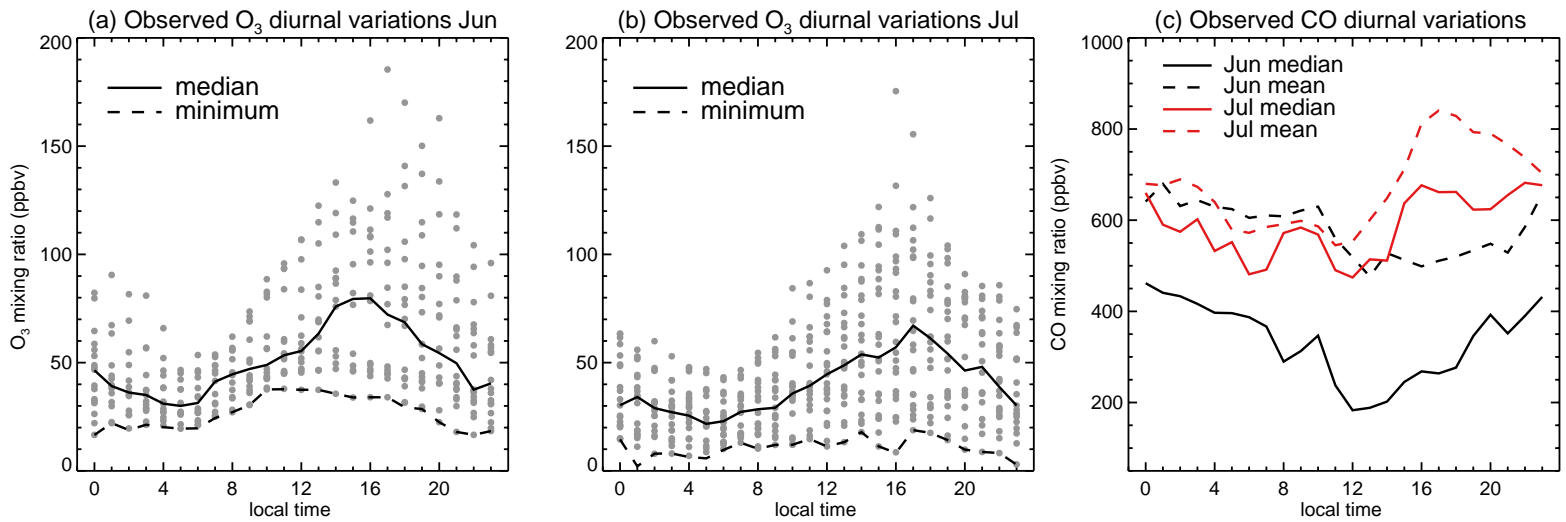

Fig. 3. Diurnal variations of $\mathrm{O}_{3}(\mathbf{a}, \mathbf{b})$ and $\mathrm{CO}(\mathbf{c})$ observed at Miyun in June and July 2006. (a, b) Each point refers to hourly mean mixing ratios. Median and minimum $\mathrm{O}_{3}$ are indicated in the figures. (c) Median and mean $\mathrm{CO}$ as a function of local time in June and July. The large difference between mean and median CO in June implies a much skewed distribution including both the clean continental flow from the north and urban pollution plumes from the south.

shown below, have an important influence on photolysis rates of key species involved in ozone chemistry.

\subsection{Influence of cloudiness on $\mathrm{O}_{3}$}

Diurnal variations of $\mathrm{O}_{3}$ measured at Miyun in June and July are presented in Fig. 3a and b respectively. It is typical for ozone at low-elevation sites to peak in the late afternoon, resulting from photochemical production of ozone over the course of the day (Logan, 1989). $\mathrm{O}_{3}$ decreases in the evening reaching a minimum around $5 \mathrm{am}$, before sunrise. On sunny days in July, highest mixing ratios of $\mathrm{O}_{3}$ occur at 5 p.m., coincident with the peak in $\mathrm{CO}$ mixing ratios (Fig. 3c), indicating the arrival of more polluted air, consistent with the change in mean flow pattern. Mixing ratios of $\mathrm{CO}$ in June exhibit a minimum in mid-day associated with the maximum boundary layer height and peak vertical mixing (Fig. 3c). The amplitude of the diurnal variation of $\mathrm{O}_{3}$ averaged about $50 \mathrm{ppbv}$ in June. In July, however, the typical afternoon peak in $\mathrm{O}_{3}$ was not observed during one-third of the measurement days. During these days, mixing ratios of $\mathrm{O}_{3}$ were relatively low in the afternoon (below $20 \mathrm{ppbv}$ in many cases), leading to a flat diurnal pattern with little enhancement in $\mathrm{O}_{3}$ from morning to afternoon (Fig. 3b). Days with relatively low afternoon $\mathrm{O}_{3}$ in July were associated generally with rain or thunderstorm events. $\mathrm{RH}$ measured at the site during these days approached $100 \%$.

Photochemical production of $\mathrm{O}_{3}$ is suppressed in the presence of the increased cloudiness associated with the monsoon rainfall. Transmission of solar radiation below cloud level is reduced significantly during these periods with implications for photochemical production of $\mathrm{O}_{3}$ near the surface (Lefer et al., 2003; Liu et al., 2006). A significant negative correlation $(r=-0.7, n=29)$ was found in July between the daily mean COD retrieved from MODIS over the Beijing-Miyun region and mean afternoon $\mathrm{O}_{3}$ measured at the site (Fig. 4). Relatively low levels of $\mathrm{O}_{3}$ were associated usually with high COD retrieved from MODIS. The temporal correlation between the two independent datasets is striking, especially since the data were obtained from different platforms and since cloudiness is only one of the factors responsible for regulating levels of ozone, supporting the suggestion that the increase in cloudiness in July is primarily responsible for the decrease in $\mathrm{O}_{3}$ observed during this month. Since cloudiness has little effect on $\mathrm{CO}$, this can account for the insignificant correlation between $\mathrm{CO}$ and $\mathrm{O}_{3}$ observed in July.

The model fails to capture the observation of a less pronounced diurnal cycle during periods of precipitation (when afternoon $\mathrm{O}_{3}$ levels are comparatively low). COD from the GEOS-Chem model averages $60 \%$ lower than COD retrieved from MODIS in July (Fig. 4), differences reaching a factor of 10 for some low ozone days. The correlation between GEOS-Chem COD and COD retrieved from MODIS is weak $(r=0.4)$. The heterogeneity of COD on the scale of the model grid $\left(2^{\circ} \times 2.5^{\circ}\right.$ resolution $)$ is significant, as illustrated in Fig. 4 showing the range of COD retrieved by MODIS over a region of $2^{\circ} \times 3^{\circ}$ surrounding the Miyun site. In a sensitivity analysis, we scaled model COD at the Miyun grid to match values of COD retrieved from MODIS for the same location, and found a reduction of up to $10 \mathrm{ppbv}$ in afternoon mixing ratios of $\mathrm{O}_{3}$ simulated by the model during low ozone days. By comparison, $\mathrm{O}_{3}$ varied by less than $1 \mathrm{ppbv}$ in conjunction with further sensitivity tests in which we explored other consequences of increased cloudiness, such as increased wet scavenging of soluble $\mathrm{O}_{3}$ precursors (formaldehyde for example). This suggests that the model overestimate of $\mathrm{O}_{3}$ relates primarily to its underestimate of local COD at Miyun, especially during precipitation events. The adjustments in COD implemented in our simple sensitivity test cannot correct for the full extent of the model overestimate. The model, 


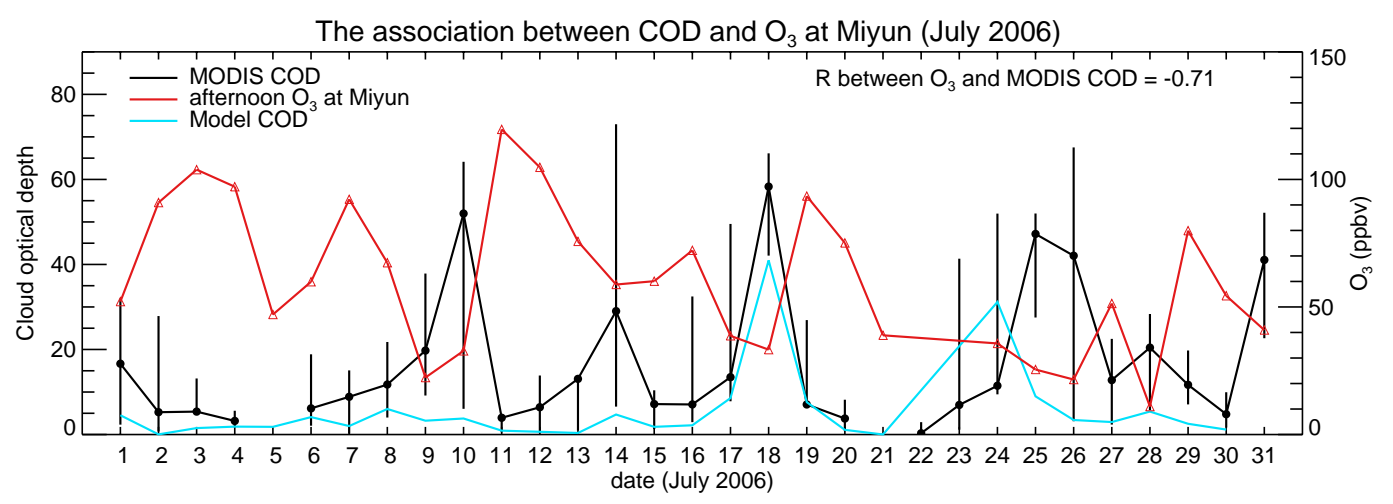

Fig. 4. The association between afternoon $\mathrm{O}_{3}$ measured at Miyun (red) and cloud optical depth retrieved from MODIS (black) for an area of $1^{\circ} \times 1^{\circ}$ including the site (MYD08_D3, level-3 daily global product) in July 2006. The range of COD retrieved from MODIS over a region of $2^{\circ} \times 3^{\circ}$ surrounding the Miyun site is indicated as vertical lines. COD from the GEOS-Chem model is indicated in blue.

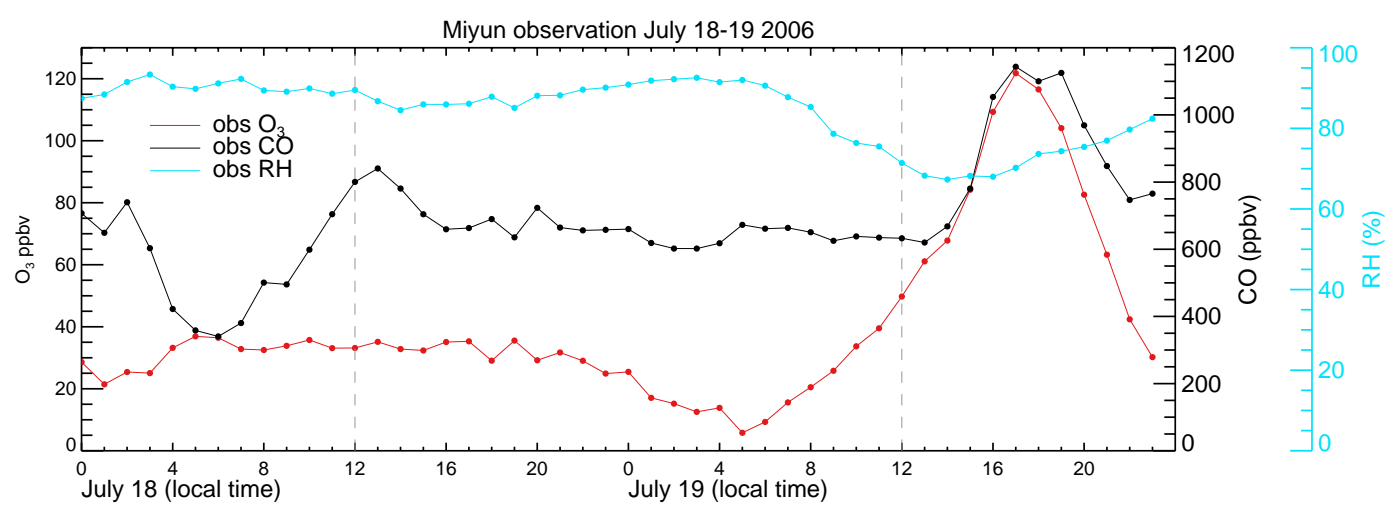

Fig. 5. Hourly measurements of $\mathrm{O}_{3}$ (red), $\mathrm{CO}$ (black), and RH (blue) at the Miyun site for the period of 18 and 19 July 2006 . The gray dashed line indicates local noon.

given its relatively coarse resolution, underestimates $\mathrm{CO}$ and probably also concentrations of $\mathrm{NO}_{\mathrm{x}}$ in the urban pollution plume reaching the site, underestimating consequently the titration effect of $\mathrm{NO}$ on $\mathrm{O}_{3}$.

The monsoonal cloud cover is a more predictable seasonal phenomenon than the scattered cumulus or intermittent frontal passages that control cloudiness in non-monsoon regions. The model demonstrates the significance of the radiative impact of monsoonal clouds on ozone. Ding et al. (2008) suggested two other causes of the seasonal peak of $\mathrm{O}_{3}$ in June over Beijing derived from multi-year records of the MOZAIC aircraft data: more intense crop residue burning in June contributing to emissions of ozone precursors, and prevailing southerly winds in June facilitating long-range transport of regional emissions to Beijing. Our observations at Miyun in summer 2006 present an interesting case that when $\mathrm{CO}$ levels were higher in July than in June, the $\mathrm{O}_{3}$ levels still decreased in July. This suggests that at least in 2006 it is the radiative effect of monsoonal clouds on surface ozone, rather than changes in local and regional precursor emissions, that plays the dominant role in reducing surface ozone levels in
July. As the East Asian summer monsoon circulation prevails across all of east China (east of the Tibetan Plateau), we expect the radiative impact of monsoonal clouds on ozone to be significant on a regional scale during summer. Consistent with our speculation, previous observations at other surface sites in east China do not show a maximum of $\mathrm{O}_{3}$ in summer (Wang et al., 2002; Luo et al., 2000).

\subsection{Case study}

A two-day period, 18 and 19 July 2006, was selected as a case study of day-to-day variations in $\mathrm{O}_{3}$ and $\mathrm{CO}$ as they relate to dynamical and/or chemical factors. Hourly $\mathrm{O}_{3}, \mathrm{CO}$, and $\mathrm{RH}$ observed at the Miyun site during the two days are presented in Fig. 5. Mixing ratios of $\mathrm{O}_{3}$ were about $35 \mathrm{ppbv}$ on 18 July with little buildup from morning to afternoon. $\mathrm{O}_{3}$ levels were significantly higher on the following day exhibiting a distinct peak in the afternoon with a maximum of 120 ppbv. RH measured at the site decreased from about $90 \%$ on 18 July to $75 \%$ on 19 July, consistent with the changes in COD retrieved from MODIS (Fig. 4) indicating a greater 
influence for rain events on 18 July. CO was generally above $600 \mathrm{ppbv}$ throughout the period after a low of $400 \mathrm{ppbv}$ on the morning of 18 July. A peak of up to $800 \mathrm{ppbv}$ in the afternoon of 18 July indicates transport of polluted air to the site, but there was no corresponding increase in $\mathrm{O}_{3}$. In contrast, the peak of 1200 ppbv in $\mathrm{CO}$ during the afternoon of 19 July coincided with the peak in $\mathrm{O}_{3}$, indicating the transport patterns may differ from the previous day. The association between changes in $\mathrm{O}_{3}, \mathrm{RH}$ and $\mathrm{COD}$ suggests that the low $\mathrm{O}_{3}$ levels on July 18 reflected suppression of $\mathrm{O}_{3}$ production associated with high COD. Simultaneous peaks in $\mathrm{O}_{3}$ and $\mathrm{CO}$ around $5 \mathrm{pm}$ on 19 July illustrate the significance of $\mathrm{O}_{3}$ produced from anthropogenic precursors transported from the Beijing urban area. The shift in the peak of $\mathrm{O}_{3}$ to 5 p.m. on 19 July as compared to 3 p.m. observed typically in June represents the lag associated with the transport of these precursors.

Wild et al. (2004), using a global chemical transport model, examined the influence of different regional meteorological processes on regional ozone production over East Asia in spring time and its global impact. Their work demonstrated in detail that cloudy, cyclonic weather systems unfavorable for boundary layer ozone production over East Asia typically allow for efficient lifting of precursors into the free troposphere where ozone is formed downwind, having a great impact on global ozone. In contrast, they found that stagnant, anticyclonic events conducive to strong ozone production over East Asia tend to keep ozone and precursors within the boundary layers, having relatively small impacts on global ozone. In light of their study, we examined the variation in $\mathrm{NO}_{\mathrm{x}}$, an important ozone precursor, during the twoday period. Although measurements of $\mathrm{NO}_{\mathrm{x}}$ are not available, we adopted model fields as the GEOS-Chem model was found to reproduce the observed variation of $\mathrm{O}_{3}, \mathrm{RH}$, and COD between 18 and 19 July. The $\mathrm{NO}_{\mathrm{x}}$ to $\mathrm{NO}_{\mathrm{y}}$ (reactive nitrogen family, the sum of $\mathrm{NO}_{\mathrm{x}}$ and its oxidation products) ratio in the boundary layer at Miyun as predicted by the GEOS-Chem model is 0.7 on 18 July (cloudy day with low mixing ratio of surface $\mathrm{O}_{3}$ ) as compared to 0.4 on 19 July (clear day with high $\mathrm{O}_{3}$ ). Simulated mixing ratios of $\mathrm{NO}_{\mathrm{x}}$ in the boundary layer are also higher on 18 July than on 19 July, partly because of an increase in the chemical lifetime of $\mathrm{NO}_{\mathrm{x}}$ below clouds. Consistent with Wild et al. (2004) springtime study, our analysis suggests that although local photochemical production of ozone is suppressed below the optically thick clouds, there is still a lot of $\mathrm{NO}_{\mathrm{x}}$ available for future ozone production when the polluted air mass is exported downwind (toward northeast in summer) or lifted to the free troposphere by convection with implications for global ozone production.

\section{Concluding remarks}

Large intra-seasonal differences in $\mathrm{CO}$ and $\mathrm{O}_{3}$ were detected at Miyun in summer. Despite the observed increases in mean daytime CO, about $200 \mathrm{ppbv}$ from June to July, mean daytime $\mathrm{O}_{3}$ decreased over the same period by $17 \mathrm{ppbv}$. Observed changes in $\mathrm{CO}$ and $\mathrm{O}_{3}$ are attributed to meteorological influences associated with the summer monsoonal circulation that develops over the North China Plain in July. The change in flow pattern associated with the onset of the summer monsoon circulation results in more frequent transport of polluted air from the Beijing urban region to the area of the north represented by Miyun. This change in circulation accounts for the increase in $\mathrm{CO}$ from June to July. The increase in COD associated with the increase in $\mathrm{RH}$ and precipitation in July has an important contrary influence on photochemical production of $\mathrm{O}_{3}$. Transmission of solar radiation to the near surface region is reduced by the presence of optically thick clouds, leading to a decrease in the photochemical production of $\mathrm{O}_{3}$ as reflected in the strong negative correlation of $\mathrm{O}_{3}$ with COD observed during July.

The analysis suggests that strategies to minimize the incidence of high levels of $\mathrm{O}_{3}$ over Beijing in summer should focus on times when forecast models suggest that upcoming conditions are likely to be relatively cloud-free. Reduction in emissions of $\mathrm{O}_{3}$ precursors during such times are likely to be most effective in limiting the number of occasions where summertime levels of $\mathrm{O}_{3}$ exceed the existing Chinese ozone air quality standard (1-h concentration of $200 \mu \mathrm{g} / \mathrm{m}^{3}$ at $1 \mathrm{~atm}$ and $25^{\circ} \mathrm{C}$, corresponding to a mixing ratio of $102 \mathrm{ppbv}$ ).

Acknowledgement. This research was supported by the National Science Foundation, grant ATM-0635548, and funds from the Harvard University Smeltzer Fund and an anonymous private foundation.

Edited by: O. Cooper

\section{References}

Andreae, M. O. and Merlet, P.: Emission of trace gases and aerosols from biomass burning, Global Biogeochem. Cy., 15, 955-966, 2001.

Bey, I., Jacob, D. J., Yantosca, R. M., Logan, J. A., Field, B., Fiore, A. M., Li, Q., Liu, H., Mickley, L. J., and Schultz, M.: Global modeling of tropospheric chemistry with assimilated meteorology: Model description and evaluation, J. Geophys. Res., 106, 23 073-23 096, 2001

Chin, M., Jacob, D. J., Munger, J. W., Parrish, D. D., and Doddridge, B. G.: Relationship of ozone and carbon monoxide over North America, J. Geophys. Res., 99, 14 565-14 573, 1994

Ding, A. J., Wang, T., Thouret, V., Cammas, J.-P., and Ndlec, P.: Tropospheric ozone climatology over Beijing: analysis of aircraft data from the MOZAIC program, Atmos. Chem. Phys., 8 , 1-13, 2008,

http://www.atmos-chem-phys.net/8/1/2008/. 
Foulger, B. E. and Simmonds, P. G.: Ambient temperature gas purifier suitable for the trace analysis of carbon monoxide and hydrogen and the preparation of low-level carbon monoxide calibration standards in the field, J. Chromatogr. A, 630(1-2), 257-263, 1993.

Gao, J., Wang, T., Ding, A., and Liu, C.: Observations study of ozone and carbon monoxide at the summit of mount Tai (1534 m a.s.1.) in central-eastern China, Atmos. Environ., 39, 4779-4791, 2005.

Heald, C. L., Jacob, D. J., Jones, D. B. A., Palmer, P. I., Logan, J. A., Streets, D. G., Sachse, G. W., Gille, J. C., Hoffman, R. N., and Nehrkorn, T.: Comparative inverse analysis of satellite (MOPITT) and aircraft (TRACE-P) observations to estimate Asian sources of carbon monoxide, J. Geophys. Res., 109, D23306, doi:10.1029/2004JD005185, 2004.

Logan, J. A.: Ozone in rural areas of the United States, J. Geophys. Res., 94, 8511-8532, 1989.

Jacob, D. J., Crawford, J. H., Kleb, M. M., Connors, V. S., Bendura, R. J., Raper, J. L., Sachse, G. W., Gille, J. C., Emmons, L., and Heald, C. L.: The Transport and Chemical Evolution over the Pacific (TRACE-P) aircraft mission: design, execution, and first results, J. Geophys. Res., 108, 9000, doi:10.1029/2002JD003276, 2003.

Lefer, B. L., Shetter, R. E., Hall, S. R., Crawford, J. H., and Olson, J. R.: Impact of clouds and aerosols on photolysis frequencies and photochemistry during TRACE-P: 1 . Analysis using radiative transfer and photochemical box models, J. Geophys. Res., 108(D21), 8821, doi:10.1029/2002JD003171, 2003.

Li, J., Wang, Z., Akimoto, H., Gao, C., Pochanart, P., and Wang, X.: Modeling study of ozone seasonal cycle in lower troposphere over east Asia, J. Geophys. Res., 112, D22S25, doi:10.1029/2006JD008209, 2007.

Liang, J., Horowitz, L. W., Jacob, D. J., Wang, Y., Fiore, A. M., Logan, J. A., Gardner, G. M., and Munger, J. W.: Seasonal variations of reactive nitrogen species and ozone over the United States, and export fluxes to the global atmosphere, J. Geophys. Res., 103, 13 435-13 450, 1998.

Lin, W., Xu, X., Zhang, X., and Tang, J.: Contributions of pollutants from North China Plain to surface ozone at the Shangdianzi GAW Station, Atmos. Chem. Phys., 8, 5889-5898, 2008, http://www.atmos-chem-phys.net/8/5889/2008/.

Liu, H., Crawford, J. H., Pierce, R. B., et al.: Radiative effect of clouds on tropospheric chemistry in a global threedimensional chemical transport model, J. Geophys. Res., 111, D20303, doi:10.1029/2005JD006403, 2006.

Luo, C., John, J. C. St., Zhou, X., Lam, K. S., Wang, T., and Chameides, W. L.: A nonurban ozone air pollution episode over eastern China: observations and model simulations, J. Geophys. Res., 105(D2), 1889-1908, 2000.

Mao, H. and Talbot, R.: $\mathrm{O}_{3}$ and $\mathrm{CO}$ in New England: Temporal variations and relationships, J. Geophys. Res., 109, D21304, doi:10.1029/2004JD004913, 2004.

NBS (National Bureau of Statistics of China): China Statistical Yearbook 2006, China Stat. Press, Beijing, 2007.

NRC (National Research Council): Rethinking the ozone problem in urban and regional air pollution, National Academy Press, Washington, D.C., 1991.

Parrish, D. D., Trainer, M., Holloway, J. S., Yee, L. E., Warshawsky, M. S., Fehsenfeld, F. C., Forbes, G. L., and Moody, J. L.: Rela- tionships between ozone and carbon monoxide at surface sites in the North Atlantic region, J. Geophys. Res., 103, 13 357-13 376, 1998.

Platnick, S., King, M. D., Ackerman, S. A., Menzel, W. P., Baum, B. A., Riedi, J. C., and Frey, R. A.: The MODIS cloud products: Algorithms and examples from Terra, IEEE Trans. Geosci. Remote Sens., 41(2), 459-473, 2003.

Streets D. G., Bond, T. C., Carmichael, G. R., et al.: An inventory of gaseous and primary aerosol emissions in Asia in the year 2000, J. Geophys. Res., 108 (D21), 8809, doi:10.1029/2002JD003093, 2003.

Streets, D. G., Zhang, Q., Wang, L., He, K., Hao, J., Wu, Y., Tang, Y., and Carmichael, G. R.: Revisiting China's CO emissions after TRACE-P: Synthesis of inventories, atmospheric modeling, and observations, J. Geophys. Res., 111, D14306, doi:10.1029/2006JD007118, 2006.

Tan, Q., Chameides, W. L., Streets, D., Wang, T., Xu, J., Bergin, M., and Woo, J.: An evaluation of TRACE-P emission inventories from China using a regional model and chemical measurements, J. Geophys. Res., 109, D22305, doi:10.1029/2004JD005071, 2004.

van der Werf, G. R., Randerson, J. T., Giglio, L., Collatz, G. J., Kasibhatla, P. S., and Arellano Jr., A. F.: Interannual variability in global biomass burning emissions from 1997 to 2004, Atmos. Chem. Phys., 6, 3423-3441, 2006,

http://www.atmos-chem-phys.net/6/3423/2006/.

Wang, T., Cheung, T. F., Li, Y. S., Xu, X. M., and Blake, D. R.: Emission characteristics of $\mathrm{CO}, \mathrm{NOx}, \mathrm{SO}_{2}$ and indications of biomass burning observed at a rural site in eastern China, J. Geophys. Res., 107(D12), 4157, doi:10.1029/2001JD000724, 2002.

Wang, Y. X., McElroy, M. B., Wang, T., and Palmer, P. I.: Asian emissions of $\mathrm{CO}$ and $\mathrm{NO}_{\mathrm{X}}$ : Constraints from aircraft and Chinese station data, J. Geophys. Res., 109, D24304, doi:10.1029/2004JD005250, 2004a.

Wang, T., Wong, C. H., Cheung, T. F., Blake, D. R., Arimoto, R., Baumann, K., Tang, J., Ding, G. A., Yu, X. M., Li, Y. S., Streets, D. G., and Simpson, I. J.: Relationships of trace gases and aerosols and the emission characteristics at Lin'an, a rural site in eastern China during spring 2001, J. Geophys. Res. 109, D19S05, doi:10.1029/2003JD004119, 2004b.

Wang, Y. X., McElroy, M. B., Jacob, D. J., and Yantosca, R. M.: A nested grid formulation for chemical transport over Asia: Applications to CO, J. Geophys. Res., 109, D22307, doi:10.1029/2004JD005237, 2004c.

Wang, T., Ding, A., Gao, J., and Wu, W. S.: Strong ozone production in urban plumes from Beijing, China, Geophys. Res. Lett., 33, L21806, doi:10.1029/2006GL027689, 2006.

Wang, Y. X., McElroy, M. B., Martin, R. V., Streets, D. G., Zhang, Q., and Fu, T. M.: Seasonal variability of $\mathrm{NO}_{\mathrm{X}}$ emissions over east China constrained by satellite observations: Implications for combustion and microbial sources, J. Geophys. Res., 112, D06301, doi:10.1029/2006JD007538, 2007a.

Wang, Y. X., McElroy, M. B., Boersma, K. F., Eskes, H. J., and Veefkind, J. P.: Traffic Restrictions Associated with the SinoAfrican Summit: Reductions of NOx Detected from Space, Geophys. Res. Lett., 34, L08814, doi:10.1029/2007GL029326, 2007b.

Wild, O., Prather, M. J., Akimoto, H., Sundet, J. K., et al.: Chemical transport model ozone simulations for spring 2001 over the west- 
ern Pacific: Regional ozone production and its global impacts, J. Geophys. Res., 109, D15S02, doi:10.1029/2003JD004041, 2004.

Wild, O., Zhu, X., and Prather, M. J.: Fast-J: Accurate simulation of in- and below cloud photolysis in tropospheric chemical models, J. Atmos. Chem., 37, 245-282, 2000.
Zhang, Q., Streets, D. G., He, K. B., et al.: $\mathrm{NO}_{\mathrm{x}}$ emission trends for China, 1995-2004: The view from the ground and the view from space, J. Geophys. Res., 112, D22306, doi:10.1029/2007JD008684, 2007. 